\title{
Method for Estimation of Toxic Endotoxin in Inactivated Salmonella Vaccine in D- Galactosamine-Sensitized Mice
}

\author{
Noriyasu TAKIKAWA ${ }^{1)}$, Kazuyoshi KAWAHARA ${ }^{1)}$, Akira SAWATA ${ }^{1)}$ and Katsumi KUME ${ }^{1)}$ \\ ${ }^{1)}$ Research Center for Biologicals, The Kitasato Institute, 6-111 Arai, Kitamoto, Saitama 364-0026, Japan
}

(Received 12 March 2004/Accepted 22 July 2004)

ABSTRACT. We developed a method to estimate the content of the toxic endotoxin in inactivated Salmonella vaccine in D-galactosaminesensitized mice. Ten-fold serially diluted vaccines were injected intraperitoneally into D-galactosamine-sensitized mice. Lethality in the mice was judged 3 days after the injection. The best result was obtained when $\mathrm{C} 3 \mathrm{H} / \mathrm{HeN}$ mice were used for the test. Correlation was observed between the endotoxin content measured by Limulus amoebocyte lysate assay and the $\mathrm{LD}_{50}$ in the mouse safety test ( $\mathrm{r}=0.81$ ). These results suggested that this test could be applied to the estimation of endotoxin content in inactivated vaccines of Salmonella. KEY WORDS: endotoxin, Salmonella, vaccine.

Endotoxin (lipopolysaccharide) is a surface component of gram-negative bacteria, and it exhibits various biological activities when it is released from bacterial cells [13]. Endotoxin causes various symptoms including a state of shock and pyrexia in the animal $[1,5,9]$. Rieder and Thomas [12] reported that intravenously injected E. coli endotoxin caused abortion in mice. Cattle manifest clinical signs of shock, tachypnea, dyspnea and a significant increase in the respiratory rate within a short time, and inflammatory cytokines of tumor necrosis factor, interleukin-1 rapidly raised in the blood within a few hours after injection of endotoxin [1, 10]. Kreeftenberg et al. [8] reported that free endotoxin in the supernatant of inactivated typhoid vaccine reacted stronger than the cell-associated endotoxin in the sediment in the rabbit pyrogenicity test. Hussaini and Ready [7] reported that a high level of free endotoxin contained in the vaccine caused abortion in sows, whereas a low level did not.

Limulus amoebocyte lysate (LAL) assay has been used to measure endotoxin content in the vaccine of gram-negative bacteria [6-8]. This assay is sensitive and rapid, recently used widely in many laboratories, and was introduced into the Japanese pharmacopoeia. However, this method is based on a clotting system of Limulus amobocyte, and there is the possibility that LAL assay could not estimate the toxic endotoxin in cattle. Therefore, an in vivo assay system with laboratory animals is urgently required. D-galactosamine (GalN)-sensitized mice increased the sensitivity up to 100,000-fold to lethal effects of endotoxin [2-4]. Based on this knowledge, we applied GalN-sensitized mice for the estimation of the endotoxin content in inactivated Salmonella vaccine.

Fifteen batches of inactivated Salmonella vaccine containing various amounts of endotoxin ranging from 250 to 241,300 endotoxin units (EU)/m $l$ measured by LAL assay (Endospecy, Seikagaku Kogyo Co., Tokyo, Japan) were prepared. These vaccines contained formalin-inactivated cells of Salmonella enterica serovar Typhimurium (ST) and
S. enterica serovar Dublin (SD) (approx. ST: $1.0 \times 10^{10}$ cells $/ \mathrm{m} l$, SD: $2.5 \times 10^{10}$ cells $\left./ \mathrm{m} l\right)$.

Four strains of mice (ddY, ICR, BALB/c and C3H/HeN, 10-weeks old, Japan SLC, Hamamatsu, Japan) were used in this experiment. Each mouse was injected intraperitoneally with $10 \mathrm{mg}$ of GalN (Wako Pure Chemical, Osaka, Japan) dissolved in distilled water. Immediately after the GalN injection, an aliquots $(0.5 \mathrm{ml})$ of 10 -fold serially diluted vaccines with Dalbecco modified phosphate buffer saline (Nissui Pharmaceutical, Tokyo, Japan) were injected intraperitoneally. Lethality in the mice was judged 3 days after the injection. All of the experiments in this study were performed according to the Guidelines for Animal Experiments of The Kitasato Institute, Saitama, Japan.

In the first experiment, the lethality of the vaccine (batch No. 4) in 4 mice strains was examined. As shown in Table 1 , ddY and ICR mice were less sensitive to the vaccine than $\mathrm{BALB} / \mathrm{c}$ and $\mathrm{C} 3 \mathrm{H} / \mathrm{HeN}$ mice. The $\mathrm{LD}_{50}$ value for each strain of mice was reproducible in the repeated experiments. In the next experiment, the lethality of 4 batches of vaccine with different endotoxin contents was tested on BALB/c and $\mathrm{C} 3 \mathrm{H} / \mathrm{HeN}$ mice. In both tests with different mice strains, the $\mathrm{LD}_{50}$ values correlated well with the amounts of endotoxin (Table 2), but in the tests for batch No.2 of BALB/c mice,

Table 1. Lethality of the inactivated Salmonella vaccine against 4 strains of D-galactosamine-sensitized mice

\begin{tabular}{ccccc}
\hline \multirow{2}{*}{$\begin{array}{c}\text { Vaccine } \\
\text { dilution }\end{array}$} & \multicolumn{4}{c}{ Strain of mice } \\
\cline { 2 - 5 } & ddY & ICR & BALB/c & C3H/HeN \\
\hline $10^{1}$ & $2 / 5^{\text {b) }}$ & $1 / 5$ & $5 / 5$ & $5 / 5$ \\
$10^{2}$ & $2 / 5$ & $1 / 5$ & $2 / 5$ & $5 / 5$ \\
$10^{3}$ & $0 / 5$ & $0 / 5$ & $1 / 5$ & $3 / 5$ \\
$10^{4}$ & $0 / 5$ & $0 / 5$ & $0 / 5$ & $0 / 5$ \\
\hline $\mathrm{LD}_{50}(\log )$ & 0.9 & 0.9 & 2.1 & 3.1 \\
\hline
\end{tabular}

a) Vaccine batch No.4 (241,300 endotoxin unit/m $l$ measured by LAL assay) was used in this experiment.

b) Dead mice/tested mice. 
Table 2. Lethality of 4 batches of the vaccine against $\mathrm{BALB} / \mathrm{c}$ and $\mathrm{C} 3 \mathrm{H} / \mathrm{HeN}$ mice

\begin{tabular}{|c|c|c|c|c|c|c|c|c|}
\hline \multirow{3}{*}{ Vaccine dilution } & \multicolumn{4}{|c|}{$\mathrm{BALB} / \mathrm{c}$ mice } & \multicolumn{4}{|c|}{$\mathrm{C} 3 \mathrm{H} / \mathrm{HeN}$ mice } \\
\hline & \multicolumn{4}{|c|}{ Vaccine batch No. } & \multicolumn{4}{|c|}{ Vaccine batch No. } \\
\hline & 1 & 2 & 3 & 4 & 1 & 2 & 3 & 4 \\
\hline $10^{0}$ & $8 / 10^{\text {a) }}$ & $5 / 10$ & $9 / 10$ & $10 / 10$ & $9 / 10$ & $10 / 10$ & $10 / 10$ & $10 / 10$ \\
\hline $10^{1}$ & $8 / 10$ & $6 / 10$ & $8 / 10$ & $10 / 10$ & $5 / 10$ & $8 / 10$ & $10 / 10$ & $10 / 10$ \\
\hline $10^{2}$ & $2 / 10$ & $8 / 10$ & $7 / 10$ & $10 / 10$ & $0 / 10$ & $4 / 10$ & $9 / 10$ & $10 / 10$ \\
\hline $10^{3}$ & $0 / 10$ & $5 / 10$ & $5 / 10$ & $6 / 10$ & $0 / 10$ & $0 / 10$ & $0 / 10$ & $4 / 10$ \\
\hline $10^{4}$ & NT & $0 / 10$ & $0 / 10$ & $0 / 10$ & NT & NT & NT & $0 / 10$ \\
\hline $\mathrm{LD}_{50}(\log )$ & 1.3 & 1.7 & 2.4 & 3.1 & 0.9 & 1.7 & 2.4 & 2.9 \\
\hline Endotoxin $(\mathrm{EU} / \mathrm{m} l)$ & 4,200 & 10,500 & 104,600 & 241,300 & 4,200 & 10,500 & 104,600 & 241,300 \\
\hline
\end{tabular}

a) Dead mice/tested mice.

the dilution rate of the vaccine and the number of dead mice did not correlate (Table 2). These phenomena, did not often, occur except when BALB/c mice were used for the tests.

In order to confirm the toxicity factor contained in the vaccine, the lethality to $\mathrm{C} 3 \mathrm{H} / \mathrm{HeN}$ mice and the endotoxin low-responders among $\mathrm{C} 3 \mathrm{H} / \mathrm{HeJ}$ mice, harboring the mutation in the endotoxin receptor (TLR-4) gene [2, 11], were compared. As shown in Table 3, all $\mathrm{C} 3 \mathrm{H} / \mathrm{HeN}$ mice died at the endotoxin dose of $0.5 \mu \mathrm{g} /$ mouse, whereas $\mathrm{C} 3 \mathrm{H} / \mathrm{HeJ}$ mice survived even at the dose of $5 \mu \mathrm{g} /$ mouse. Next, the effect of polymyxin B (Wako Pure Chemical, Osaka, Japan), which neutralizes endotoxin [14], was examined. Polymyxin B (500-fold the weight of the endotoxin) was mixed with vaccine, the mixture was incubated at room temperature for $30 \mathrm{~min}$, and tested for lethality. All of the mice injected with the non-treated vaccine were dead, but all of the mice injected with the polymyxin B-treated vaccine survived (Table 4). These results clearly indicated that the toxic factor in the vaccine is the endotoxin.

As reported previously by other groups [7, 8], the toxicity of endotoxin is supposed to be associated with free endotoxin. This hypothesis was confirmed also in this study as follows. The vaccine (batch No. 4) was centrifuged (1,400 $\times \mathrm{g}$ ) for $15 \mathrm{~min}$, and the mouse lethality of the supernatant was compared with that of the original vaccine. About $90 \%$ of the lethal activity was found to be present in the supernatant, indicating that the free endotoxin released from the bacterial cell membrane is responsible for the lethal toxicity. In this experiment, the lethal toxicity of the supernatant (without the aluminum adjuvant) and the original vaccine (with the adjuvant) had almost the same score. This suggests that the influence of the adjuvant on the lethality is not large in this test (Table 5).

$\mathrm{BALB} / \mathrm{c}$ and $\mathrm{C} 3 \mathrm{H} / \mathrm{HeN}$ mice were shown to be more sensitive to endotoxin than $\mathrm{ddY}$ and ICR mice. In addition, the lethality in $\mathrm{C} 3 \mathrm{H} / \mathrm{HeN}$ mice was more stable and reproducible than that in BALB/c mice. Therefore, we propose to use $\mathrm{C} 3 \mathrm{H} / \mathrm{HeN}$ mice for this test developed in this study, designated as the mouse safety test.

Since a correlation was observed between the lethality and LAL assay value in the experiments shown in Table 2, the data for both tests were further compared with all
Table 3. Lethality of the inactivated Salmonella vaccine and the authentic LPS against D-galactosamine-sensitized C3H/ $\mathrm{HeN}$ and $\mathrm{C} 3 \mathrm{H} / \mathrm{HeJ}$ mice

\begin{tabular}{lccccc}
\hline \multirow{2}{*}{ Mouse } & \multicolumn{2}{c}{$\begin{array}{c}\text { Vaccine } \\
\text { Endotoxin by LAL }(\mu \mathrm{g} / \mathrm{m} l)^{\mathrm{a})}\end{array}$} & & \multicolumn{2}{c}{$\mathrm{LPS}^{\mathrm{b})}$} \\
\cline { 2 - 3 } \cline { 5 - 6 } & 10 & 1 & & 10 & 1 \\
\cline { 2 - 3 } & $10 / 10^{\mathrm{c})}$ & $10 / 10$ & & $10 / 10$ & $10 / 10$ \\
$\mathrm{C} 3 \mathrm{H} / \mathrm{HeN}$ & $0 / 10$ & $0 / 10$ & & $0 / 10$ & $0 / 10$ \\
$\mathrm{C} 3 \mathrm{H} / \mathrm{HeJ}$ & & & &
\end{tabular}

a) Measured by LAL assay with LPS from E. coli O111:B4 as reference $(1 \mu \mathrm{g}=2,400 \mathrm{EU} / \mathrm{m} l)$.

b) LPS from S. enterica serovar Typhimurium (Sigma).

c) Dead mice/tested mice.

Table 4. Neutralization of the lethality against D-galactosamine-sensitized $\mathrm{C} 3 \mathrm{H} / \mathrm{HeN}$ mice by polymyxin $\mathrm{B}$

\begin{tabular}{cccccc}
\hline \multirow{2}{*}{ Polymyxin B } & \multicolumn{2}{c}{ Vaccine } & & \multicolumn{2}{c}{$\mathrm{LPS}^{\mathrm{b})}$} \\
& Endotoxin by LAL $(\mu \mathrm{g} / \mathrm{m} l)^{\mathrm{a})}$ & & \multicolumn{2}{c}{$(\mu \mathrm{g} / \mathrm{m} l)$} \\
\cline { 2 - 3 } \cline { 5 - 6 }+ & 10 & 1 & & 10 & 1 \\
\hline- & $\left.0 / 10^{\mathrm{c}}\right)$ & $0 / 10$ & & $0 / 10$ & $0 / 10$ \\
\cline { 5 - 6 } & $10 / 10$ & $10 / 10$ & & $10 / 10$ & $10 / 10$ \\
\hline
\end{tabular}

a) Measured by LAL assay with LPS from E. coli O111:B4 as reference. $(1 \mu \mathrm{g}=2,400 \mathrm{EU} / \mathrm{m} l)$.

b) LPS from $S$. enterica serovar Typhimurium (Sigma).

c) Dead mice/tested mice.

Table 5. Lethality of free and cell associated endotoxin in inactivated Salmonella vaccine

\begin{tabular}{cccc}
\hline Test & Original vaccine $\left.^{\mathrm{a}}\right)$ & Supernatant & Sediment \\
\hline LAL $(\mathrm{EU} / \mathrm{m} l)$ & 241,000 & 148,000 & 20,500 \\
\hline $\begin{array}{c}\text { Lethality in mouse } \\
\text { test }\left(\mathrm{LD}_{50} \log \right)\end{array}$ & 3.1 & 3.2 & 1.9 \\
\hline
\end{tabular}

a) Vaccine batch No. $4(241,300 \mathrm{EU} / \mathrm{m} l)$ was used in this experiment.

batches of vaccine prepared. As shown in Fig. 1, the data for both tests correlated well with the value, $r=0.81$ (Spearman's correlation coefficient), and the value of significance, $P<0.01$, but the deviation of the data was rather high. This is probably due to the difference between the bacteria and methods used in the LAL assay and the mouse safety test. 


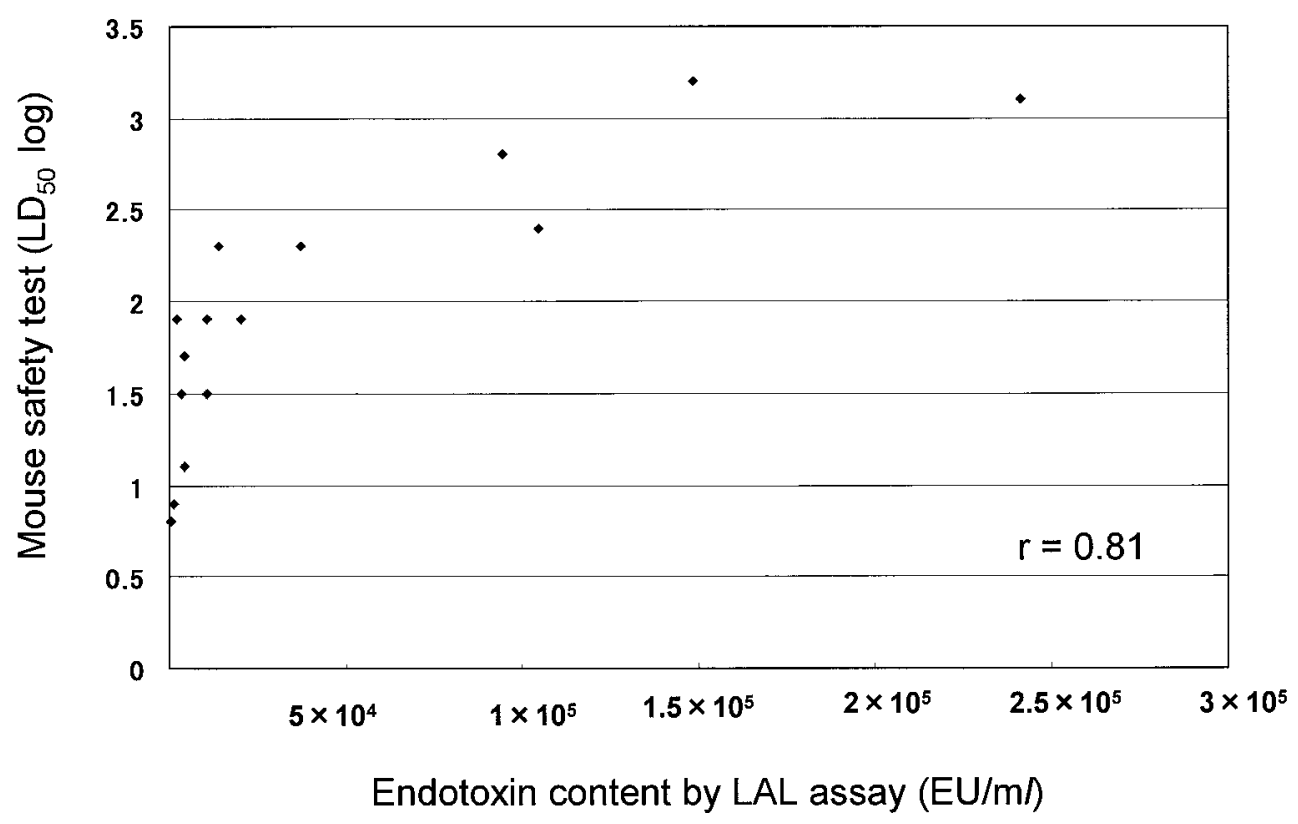

Fig. 1. Correlation between endotoxin content and $\mathrm{LD}_{50}$ in the mouse safety test. Each batch of the vaccine was tested by LAL assay and the mouse safety test. $\mathrm{C} 3 \mathrm{H} / \mathrm{HeN}$ mice were used for the test.

The in vivo assay with GalN-sensitized mouse is more suitable to estimate the toxicity of biologically active endotoxin, or free endotoxin, in cattle than in vitro LAL assay. Moreover, there is the possibility that endotoxin content can not be measured by LAL assay, in case the vaccine contains oil adjuvant. Therefore, this mouse safety test can be used for the estimation of the content of the toxic endotoxin in the inactivated Salmonella vaccine, and might also be applied to inactivated vaccines of the other gram-negative bacteria.

\section{REFERENCES}

1. Cullor, J. S. 1984. J. Am. Vet. Med. Assoc. 200: 1894-1902.

2. Freudenberg, M. A., Keppler, D. and Galanos, C. 1986. Infect. Immun. 51: 891-895.

3. Freudenberg, M. A. and Galanos, C. 1991. Infect. Immun. 59: 2110-2115.

4. Galanos, C., Freuenberg, M. A. and Reutter, W. 1979. Proc. Natl. Acad. Sci. U.S.A. 76: 5939-5943.

5. Grisman, S. E. and Hornick, R. B. 1969. Proc. Soc. Exp. Biol.

\section{Med. 131: 1154-1158.}

6. Hussaini, S. N. and Ready, R. A. 1981. Vet. Res Commun. 5: 171-175.

7. Hussaini, S. N. and Sawtell, J. A. A. 1986. Develop. Biol. Standard. 64: 261-269.

8. Kreeftenberg, J. G., Loggen, H. G., Ramshort, J. D. and Beuvery, E. C. 1976. Develop. Boil. Standard. 34: 15-20.

9. Mullenax, C. H., Keeler, R. F. and Allison, M. J. 1966. Am. J. Vet. Res. 27: 857-868.

10. Ohtsuka, H., Ohki, K., Tanaka, T., Tajima, M., Yoshino, T. and Takahashi, K. 1997. J. Vet. Med. Sci. 59: 927-929.

11. Poltorak, A., He, X., Smirnova, I., Liu, MY., Van Huffel, C., Du, X., Birdwell, D., Alejos, E., Silva, M., Galanos, C., Freudenberg, M., Ricciardi-Castagnoli, P., Layton, B. and Beuter, B. 1998. Science 282: 2085-2088.

12. Rieder, R. F. and Thomas, L. 1960. J. Immunol. 84: 189-193.

13. Rietsched, E., Brade, L., Lindner, B. and Zahringer, U. 1999. pp. 3-4. In: Bacterial Endotoxic: Lipopolysaccharides vol.I (Morrison, D. C. and Ryan, J. L. eds.), CRC Press, Boca Raton, U. S. A.

14. Rifkind, D. 1967. J. Bacteriol. 93: 1463-1464. 